\title{
Mechanisms of Beta Cell Dysfunction Associated With Viral Infection
}

\author{
Antje Petzold $^{1,2} \cdot$ Michele Solimena $^{1,2,3} \cdot$ Klaus-Peter Knoch ${ }^{1,2}$
}

Published online: 18 August 2015

(C) The Author(s) 2015. This article is published with open access at Springerlink.com

\begin{abstract}
Type 1 diabetes (T1D) results from genetic predisposition and environmental factors leading to the autoimmune destruction of pancreatic beta cells. Recently, a rapid increase in the incidence of childhood T1D has been observed worldwide; this is too fast to be explained by genetic factors alone, pointing to the spreading of environmental factors linked to the disease. Enteroviruses (EVs) are perhaps the most investigated environmental agents in relationship to the pathogenesis of T1D. While several studies point to the likelihood of such correlation, epidemiological evidence in its support is inconclusive or in some instances even against it. Hence, it is still unknown if and how EVs are involved in the development of T1D. Here we review recent findings concerning the biology of EV in beta cells and the potential implications of this knowledge for the understanding of beta cell dysfunction and autoimmune destruction in T1D.
\end{abstract}

This article is part of the Topical Collection on Pathogenesis of Type 1 Diabetes

Michele Solimena

michele.solimena@tu-dresden.de

Antje Petzold

antje.petzold@mailbox.tu-dresden.de

Klaus-Peter Knoch

klaus.knoch@mailbox.tu-dresden.de

1 Paul Langerhans Institute Dresden of the Helmholtz Center Munich at University Hospital Carl Gustav Carus and Faculty of Medicine, Technische Universität Dresden, Fetscherstr.74, 01307 Dresden, Germany

2 German Center for Diabetes Research (DZD e.V.), Neuherberg, Germany

3 Max Planck Institute of Molecular Cell Biology and Genetics, Dresden, Germany
Keywords Type 1 diabetes $\cdot$ Beta cell $\cdot$ Enterovirus $\cdot$ Coxsackievirus

\section{Introduction}

In type 1 diabetes (T1D), the insulin-producing pancreatic beta cells are destroyed by misguided immune cells. The incidence of childhood T1D has increased annually by $\sim 3 \%$, worldwide, although regional differences exist $[1,2]$. Genetic as well as environmental factors affecting the immune system and possibly beta cells contribute to the development of the disease. More than 40 genetic loci associated with T1D have been identified including those of insulin, cytotoxic $\mathrm{T}$ lymphocyte antigen 4 (CTLA-4), interleukin 2 receptor a (IL2RA), tyrosine phosphatase PTPN22, and the viral double-stranded RNA (dsRNA) sensor IFIH1 [3]. However, human leukocyte antigen (HLA) loci, and in particular selected HLA class II DR and DQ alleles, confer the strongest risk being associated with $\sim 40 \%$ of T1D cases, clearly indicating that susceptibility for the disease is at least partially inherited [4]. Furthermore, regional differences in the incidence of T1D can be attributed, at least in part, to the varying frequencies of HLA haplotypes among different populations [5]. On the other hand, studies conducted in several countries have revealed that concordance for the disease among monozygotic twins does not exceed $50 \%$, as it would be expected if T1D were to be caused by genetic factors alone [6, 7]. Additionally, migration studies have shown that children of immigrants, who moved from an area with a low incidence to an area of high incidence of T1D, increased their risk for developing the disease compared to children in the area of origin $[8,9]$. Taken together, these data point to the contribution of environmental factors toward the onset and/or progression of autoimmunity directed against beta cells. 


\section{Viruses as Agents for T1D}

Several viruses, including cytomegalovirus [10], Epstein-Barr virus [11], mumps virus [12, 13], rotavirus [14], and rubella virus [15] are among the environmental factors thought to foster the development of T1D. Above all, enteroviruses (EVs), and especially coxsackievirus B (CVB), have been linked to the disease.

Animal models for virus induction of diabetes exist since 1968, when it was first shown that infection of adult mice with encephalomyocarditis virus resulted in persistent hyperglycemia secondary to degranulation and focal necrosis of islet beta cells [16]. Subsequent studies in the non-obese diabetic (NOD) mouse, which spontaneously develops insulitis and autoimmune diabetes, pointed to the ability of both CVB3 and CVB4, also picornaviruses, to accelerate the onset of T1D in old prediabetic animals with established insulitis [17, 18]. On the other hand, infection of young NOD mice with different strains of CVB3 and CVB4 reduced the incidence of T1D onset [19]. From these data, one can conclude that the timing of infection might play a major role. Nevertheless, also various other factors such as the viral dose, the viral strain, and/or the species infected by the virus might be of importance. Findings from animal models might not necessarily reflect the conditions in human and, therefore, extrapolation from one species to another should be evaluated carefully.

In 1969, Gamble and colleagues first reported the occurrence of higher titer of neutralizing antibodies against CVB4 in recently diagnosed T1D patients [20]. These authors also noted a seasonal pattern of T1D onset with incidence increasing in late fall and early winter following outbreaks of CVB infection [21]. A decade later, Yoon and colleagues isolated CVB4 from the pancreas of a child, who died from diabetic ketoacidosis immediately after the onset of the disease, and induced diabetes in mice infected with the isolated virus [22]. This was followed by further serological studies showing a correlation between T1D and EV infection [23, 24]. However, a meta-analysis including 26 serological case-control studies found no convincing evidence for a correlation between CVB serology and T1D [25]. Yet, blood samples from recent-onset T1D patients were found positive for enteroviral RNA by PCR [26, 27]. Moreover, enteroviral RNA and capsid protein VP1 were detected in islets of pancreatic autopsy specimens from patients with T1D [28-30]. In addition, another metaanalysis of 24 retrospective and prospective studies found a significant association between T1D-related autoimmunity and EV infection, as detected by measuring enteroviral RNA or protein in stool, blood, or tissue [31]. Conversely, nextgeneration sequencing of plasma samples from children with rapid-onset T1D did not provide evidence for correlation with enteroviral infection [32]. More recently, Krogvold et al. reported the expression of VP1 in $<2 \%$ of islets and low levels of enteroviral RNA in pancreatic biopsies from seven T1D subjects and thus postulated that a low-grade infection of islet cells contributes to the development of the disease [33••]. On the other hand, EV infection might be responsible for a fulminant form of T1D reported in Japan, which is characterized by massive beta cell destruction in the absence of autoantibodies against beta cell antigens $[34,35]$.

As in mice, some CVB strains may protect from the development of T1D in humans. In Finnish children, the presence of neutralizing antibodies against CVB1 was recently shown to be associated with an increased risk of beta cell autoimmunity, while neutralizing antibodies to CVB3 and CVB6 correlated with a reduced risk for T1D [36••]. Due to the close phylogenetic relatedness of these three CVB serotypes, the authors suggested that CVB3/CVB6-specific T cells may induce an immunological cross-protection against the diabetogenic effect of a later CVB1 infection. Similar findings were also reported in a second study, which found the frequency of antibodies against CVB1 to be higher in diabetic children compared to controls [37•].

These discrepancies about the role of EVs in the development of T1D in humans could reflect the different effects of different strains in different populations and the limitations of many studies (size of cohorts, types, timing, and frequency of sampling). Most recently, a nationwide, population-based cohort study in Taiwan concluded that EV infection is associated with an increased risk of childhood T1D [38]. Also, repeated infections rather than a single event as well as the concomitance of other predisposing environmental factors might be needed for the development of the disease, which would make more difficult to prove an association. Furthermore, laboratory protocols have not been standardized and thus thresholds for detection may vary considerably, while transient infections may escape detection. Hence, despite the progressive applications of more sensitive and accurate methodologies, a consensus about a link between viral infection and the onset of T1D has yet to be reached. In light of this uncertainty, the acquisition of knowledge about the biology of viruses in beta cells may be useful.

\section{Enteroviruses}

The genus of Enterovirus belongs to the family of Picornaviridae and is grouped into 12 species named Enterovirus $A-J$ and Rhinovirus $A-C$, for a total of $>100$ serotypes including poliovirus, echovirus, coxsackievirus $\mathrm{A}$ and $\mathrm{B}$, and others [39]. EVs are common in humans and infect billions of people every year. Among them, CVB has been the most frequently associated with T1D. CVB can cause acute inflammatory diseases like myocarditis, meningitis, and pancreatitis but mostly induce milder symptoms such as fever, summer cold, or rash, or is completely asymptomatic [40, 41]. They are transmitted mainly via the fecal-oral route and replicate 
primarily in the intestine and secondary target organs like the pancreas [22].

CVB seems to exhibit a specific tropism for the pancreas and beta cells in particular. For example, CVB4 is able to infect and replicate in human pancreatic islets in vitro [42]. As mentioned above, CVB3 RNA was detected in islet of autopsy pancreata from T1D patients and children who died from fulminant CV infection, but not in exocrine tissue [28]. Recently, this was corroborated by evidence of CVB5 replication exclusively in human endocrine islets, but not in exocrine clusters [43]. Additionally, VP1 was observed in beta but not alpha cells of islets from recent-onset T1D patients [29, 30]. A possible explanation for this observation is the ability of alpha cells to mount a more efficient antiviral response to CVB4 and B5 than beta cells and thus be better able to clear viral infections [44•].

CVBs are small, non-enveloped, positive-stranded RNA viruses containing an icosahedral capsid of $\sim 30 \mathrm{~nm}$ in diameter that consist of four viral proteins (VP1-VP4) [40]. To invade the host cell, they primarily use the coxsackievirus and adenovirus receptor (CAR) [45] but also the decayaccelerating factor (DAF) [46] (Table 1). CAR is expressed in both alpha and beta cells of human pancreatic islets [47] while DAF has not been detected in human islets [28]. Poliovirus receptor (PVR) and integrin $\alpha v \beta 3$ can also mediate CVB entry, as antibodies against them protected human beta cells from CVB4 and CVB5 infection [28] (Fig. 1).

Once the virus has adsorbed to the cell surface, its capsid proteins undergo conformational changes that enable its RNA genome to enter the cell, presumably through the formation of a pore within the host plasma membrane. Additionally, intake of CVB by a combination of endocytosis and macropinocytosis at tight junctions or lipid rafts has been discussed [40] [48, 49]. However, the detailed process of entry remains to be clarified. Upon genome translocation into the host cell, the sense-strand viral RNA is translated and thereafter replicated in the cytosol by exploiting the protein machinery of the host due to the limited coding capacity of its own genome. Being uncapped and lacking a poly-A tail, viral RNAs are translated in a cap-independent fashion [50] (Fig. 1). Their 5'-untranslated region, in particular, contains internal ribosome entry sites (IRESs) for the binding of IREStransacting factors (ITAFs), such as polypyrimidine tractbinding protein 1 (PTBP1, also referred to as PTB), which promote the recruitment of ribosomes to the viral RNA for translation [51]. The viral genome encodes a single polypeptide that is cleaved into several proteins by self-activated viral proteases $2 \mathrm{~A}$ and $3 \mathrm{C}$ [41]. Proteases $2 \mathrm{~A}$ and $3 \mathrm{C}$, in turn, shut down the cap-dependent translation of host mRNAs by cleaving eukaryotic translation initiation factors (eIFs) eIF4GI [52, 53] and eIF5B [54] as well as the poly(A)-binding protein (PABP) $[55,56]$ (Table 1). In this way, EVs can exploit the host translation machinery to their advantage.
Next, the four structural viral proteins VP1-VP4 selfassemble into empty capsids, whereas non-structural proteins mediate the transcription of the positive-strand RNA genome. Through RNA encapsidation and conformational changes, stable, infectious virions are generated [41]. The mechanism of viral particle release from infected cells is still unknown, and several possibilities have been postulated including changes in cell membrane permeability, lysis, and apoptosis $[57,58]$.

\section{Dysfunction of EV-Infected Beta Cells}

\section{Beta Cell Death and Proliferation}

EVs impair beta cell function and display different cytolytic effects in pancreatic beta cells with some serotypes being highly cytolytic while others replicating without apparently destroying the cell [59]. Infection of beta cells with CVB5 induces cell death via activation of the viral sensor protein kinase R (PKR), thereby reducing the expression of the antiapoptotic protein myeloid leukemia cell sequence 1 (Mcl-1) [60] (Fig. 1). Concomitantly, the pro-apoptotic protein Bim is released and activates the caspase cascade of the mitochondrial apoptosis pathway (Table 1). This was confirmed in VP1-positive beta cells of pancreatic islets from T1D patients, in which PKR was upregulated and Mcl-1 depleted [61•]. Alternatively, productive infection with CVB3, CVB4, and CVB5 can induce beta cell death in human islets with morphological changes characteristic for pyknosis, in the absence of signs for apoptosis [62]. Likewise, murine insulinoma cells infected with CVB5 died from necrosis, but not apoptosis [63••]. Furthermore, gene expression profiling of human islets infected with a lytic EV strain revealed an upregulation of pro-inflammatory cytokines interleukin $1 \alpha$ (IL- $1 \alpha)$, IL-1 $\beta$, and tumor necrosis factor $\alpha$ (TNF- $\alpha$ ) with coeval enhanced apoptosis and necrosis, the latter resulting from the depletion of ATP concomitantly with the otherwise pro-apoptotic action of the cytokines [64・•] (Fig. 1).

The generation of double-stranded RNA (dsRNA) during the process of viral replication elicits an innate immunity response through the activation of dsRNA sensors, such as Tolllike receptor 3 (TLRs), retinoic-acid-inducible gene I (RIG-I), or melanoma differentiation associated protein 5 (MDA5, also referred to as IFIH1, Table 1), all of which are indeed upregulated in human pancreatic islets upon CVB5 infection [64••, 65, 66] (Fig. 1). Activation of dsRNA sensors induces the production and secretion of cytokines and thereby initiates inflammation. Accordingly, pro-inflammatory cytokines IL$1 \alpha$, IL- $1 \beta$, IL-6, IL- 8 , TNF- $\alpha$, and type I interferons (IFNs) IFN- $\alpha$ and IFN- $\beta$ have been detected in human islets following their infection with CVB3, CVB4, or CVB5 [47, 64••, 66-68]. Among other effects, type I IFNs upregulate the 


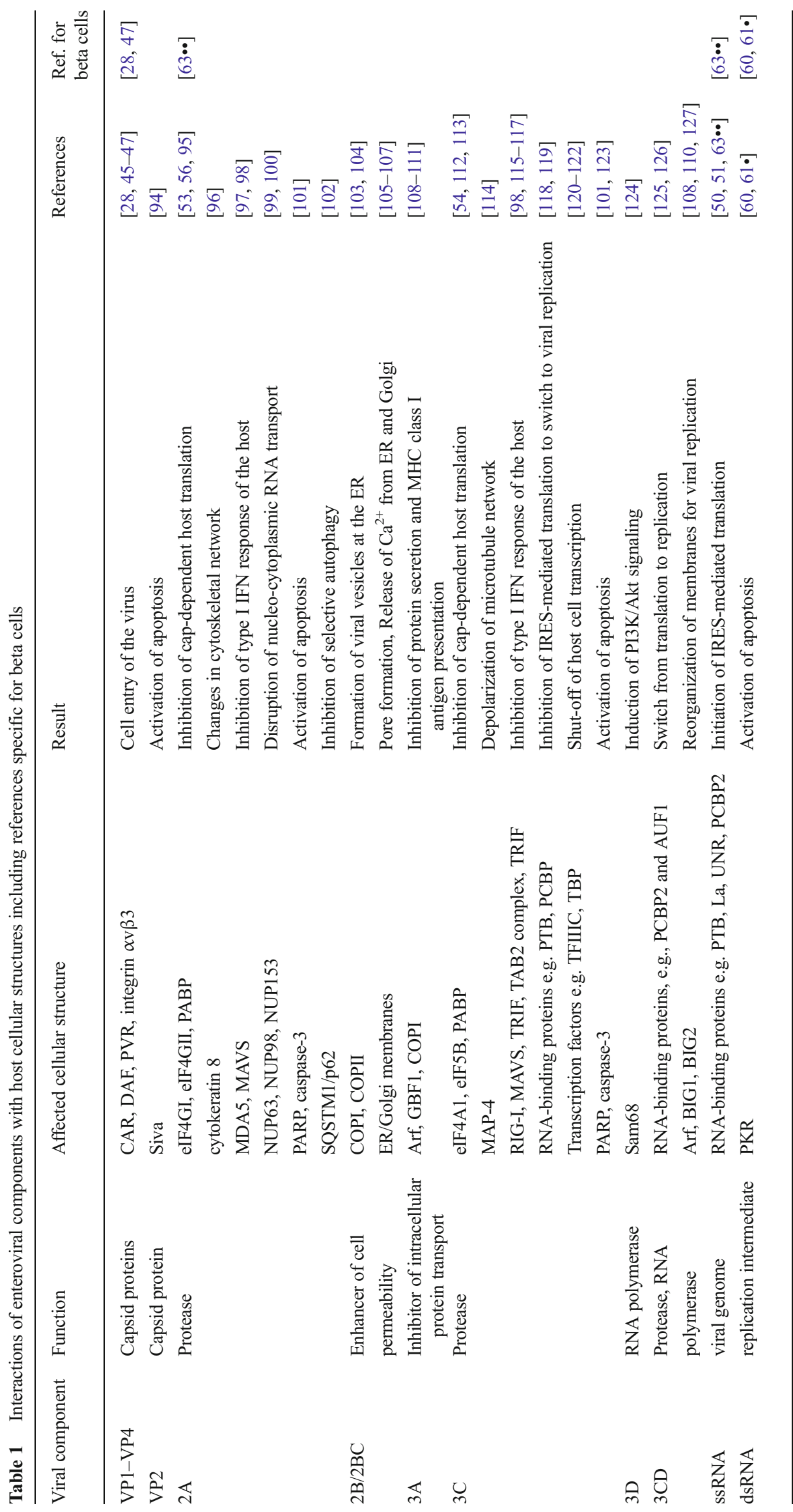




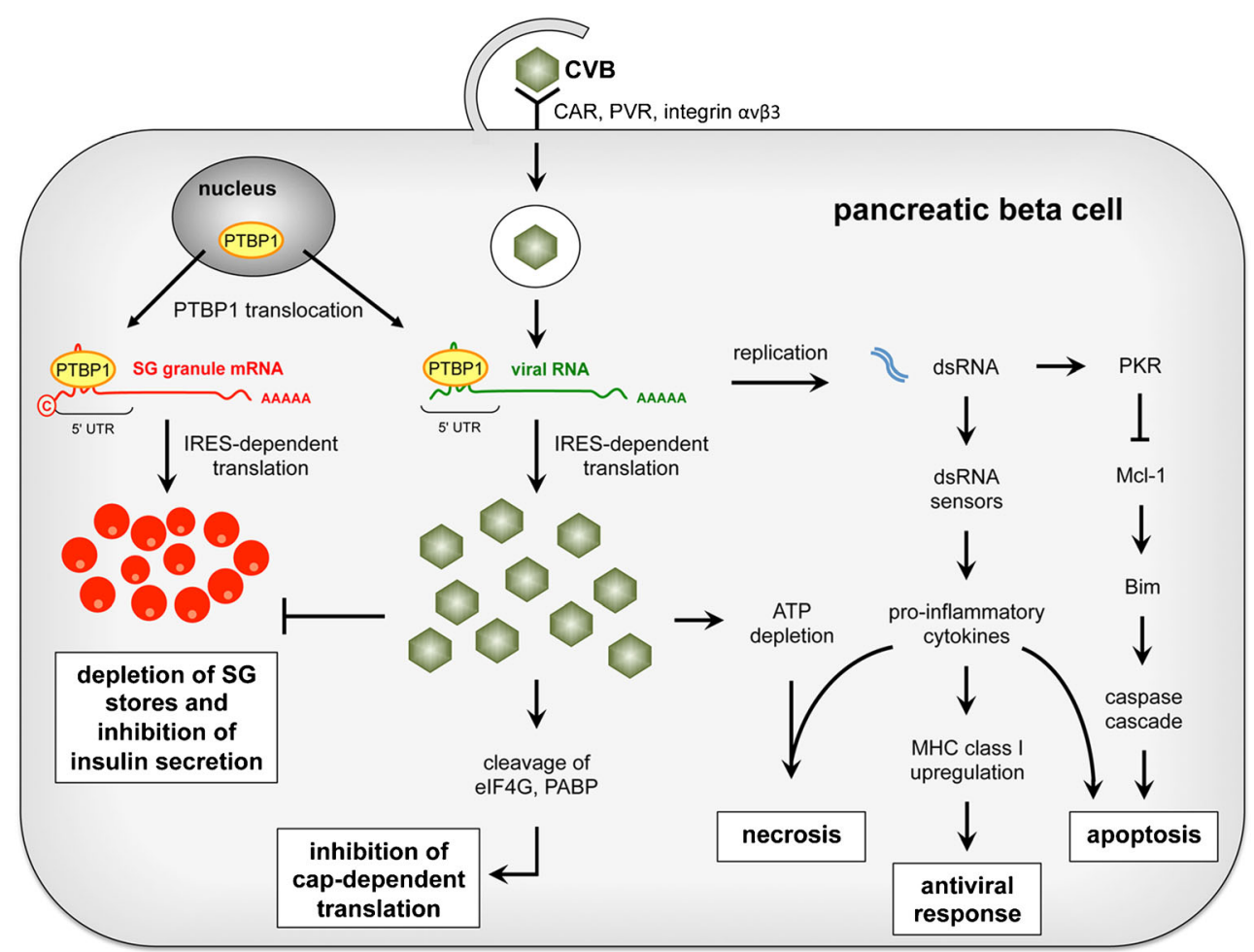

Fig. 1 Impact of CVB infection on beta cell function and survival. CVB binds to CAR, PVR, and/or integrin $\alpha \mathrm{v} \beta 3$ at the plasma membrane of the beta cell. Upon entry and translocation into the cytoplasm, the sensestranded CVB RNA is translated in a PTBP1-mediated, IRESdependent fashion by the host machinery. Cap-dependent translation of host cell proteins is inhibited through cleavage of eIF4G and PABP. Glucose-stimulated translation of insulin secretory granule (SG) cargoes is, however, unaffected being itself cap-independent and reliant on PTBP1, which in CVB-infected cells undergoes a massive nucleocytoplasmic translocation. Insulin secretion is nevertheless impaired and granule stores are depleted due to the targeting of their cargo proteins to intracellular disposal. Recognition of viral dsRNA by dsRNA sensors activates the antiviral response with production and secretion of proinflammatory cytokines and upregulation of MHC class I molecules. Additionally, dsRNA activates PKR with inhibition of the antiapoptotic Mcl-1 and thereby release of pro-apoptotic Bim and activation of the mitochondrial caspase cascade leading to apoptosis. Apoptosis can be further induced by pro-inflammatory cytokines and switch to necrosis in case of concomitant ATP depletion

in VP1-positive islets isolated from recent-onset T1D patients [72]. However, both markers were not found within the same cell. Therefore, it was suggested that factors associated with viral replication might stimulate the proliferation of neighboring, non-infected beta cells. Additionally, infection of SJL mice with a diabetogenic or with a non-diabetogenic CVB4 strain caused the acute destruction of exocrine pancreas, while islets were largely spared [73]. In the longer term, however, the infection with the non-diabetogenic strain was associated with islet neogenesis, while in the case of the diabetogenic strain, islets were also destroyed. Based on these observations, lack of beta cell neogenesis upon viral infection could contribute to beta cell depletion in mice.

\section{Insulin Production and Secretion}

Infection of isolated human islets with either CVB3, CVB4, or CVB5 reduced their insulin content and glucose-stimulated insulin secretion [42, 62]. CVB4-infected human islets transplanted in mice showed reduced insulin levels and hyperglycemia resulting in diabetes [74]. Accordingly, islets of T1D 
patients positive for CVB4 displayed also lower insulin release [29]. Gene expression profiling suggests that CVB infection downregulates factors involved in intracellular $\mathrm{Ca}^{2+}$ homeostasis and membrane potential as cause for impaired insulin secretion [64••]. In addition to insulin, other mature granule cargoes were depleted in CVB5-infected mouse islet and insulinoma cells, albeit glucose-stimulated translation of their precursor species, such as proinsulin, was unaffected [63••]. This is still possible because transcripts for most insulin granule cargoes, unlike those for most other beta cell proteins, but similar to the EV genome, are translated in a PTBP1dependent, cap-independent fashion (Fig. 1). Massive relocation of PTBP1 from the nucleus to the cytosol of CVBinfected beta cells accounts for the availability of PTBP1 in amounts sufficient to support simultaneously the translation of both viral and granule cargo transcripts. The depletion of mature granule cargoes in infected cells indicated that CVB is nevertheless able to divert the traffic of these proteins along the secretory pathway and destine them to degradation prior to secretion, which is inhibited. In some other instances, however, CVB infection could also increase the levels of released insulin, possibly due to discharge of the hormone upon beta cell damage [42].

\section{Virus-Induced Pathogenesis in T1D}

While we have acquired substantial knowledge on how EVs can directly exert a detrimental impact on beta cell function and viability, we still lack a mechanistic explanation for how this infection could also trigger or aggravate the loss of selftolerance toward beta cells. To account for these scenarios, several hypotheses have been proposed.

According to one hypothesis, viral-induced damage of infected beta cells and inflammation enhance the presentation of released beta cell peptides by professional antigen-presenting cells [75]. Concomitantly, infected beta cells upregulate their expression of MHC class I molecules in order to facilitate the presentation of viral peptides, and thus their recognition and destruction by $\mathrm{T}$ cells and the clearance of the virus. This process, however, might also enhance the antigen presentation of peptides derived from secretory granule cargoes, which in infected cells are still being translated but also massively degraded [63・•]. Whether and how such skewed presentation of granule-derived peptides accounts for the preferential loss of tolerance in T1D toward the granule cargoes proinsulin, insulin, IA-2/ICA512, IA-2 $\beta /$ phogrin, and Znt8/SLC30A8 remains to be investigated.

The related "bystander hypothesis" envisions that the release of pro-inflammatory cytokines and nitric oxide leading to insulitis and beta cell death could also follow the infection of neighboring pancreatic cells [76, 77]. In particular, there is evidence that enhanced release of islet autoantigens upon
CVB4 infection stimulates pre-existing autoreactive $\mathrm{T}$ cells and accelerates the onset of T1D in NOD mice carrying an islet-autoantigen-specific T cell receptor transgene [78]. However, this mechanism has been challenged in view of the high number of pre-existing autoreactive $\mathrm{T}$ cells required to foster disease progression [17]. Additionally, cytokines secreted by infected cells or inflammatory cells are unlikely alone to break self-tolerance $[79,80]$.

An alternative mechanism known as "molecular mimicry" implies that loss of self-tolerance may occur due to short sequence similarities between viral proteins and endogenous proteins of beta cells. Potential $\mathrm{T}$ cell crossreactivity has been documented between the $\mathrm{P} 2-\mathrm{C}$ protein of CVB4 and glutamic acid decarboxylase 65 (GAD65), a major autoantigen in T1D [81]. This hypothesis has been challenged due to experimental evidence indicating that neither autoantibodies nor autoreactive $\mathrm{T}$ cell clones isolated from T1D patients and specific for GAD65 epitopes cross-reacted with the CVB4 P2-C antigen [82, 83]. Molecular mimicry has also been proposed to occur between the rotavirus VP7 protein and IA-2/ICA512, an intrinsic protein of insulin granules and another major target of autoimmunity in T1D [84]. For instance, IA-2-restricted $\mathrm{T}$ cells were shown to proliferate upon exposure to a VP7 peptide and vice versa [85]. Additionally, IA-2 and its paralogue IA-2 $\beta$ /phogrin, also a T1D autoantigen, display sequence similarities with the enteroviral VP1 and VP0 precursor proteins with humoral cross-reactivities also occurring in both directions [86].

Prolonged inflammation due to viral persistence, replication, and antigenic stimulation has also been suggested as a potential mechanism leading to autoimmunity. For instance, some CVB strains have been reported to persist in human pancreatic islets [42, 47], presumably because of amino acid substitutions located at the surface of VP1 close to the predicted receptor binding canyon [87] or due to $5^{\prime}$ terminal deletions of the genome, which were shown to result in slower viral replication and loss of cytopathic effect [88]. Moreover, enteroviral RNA and VP1 have been detected in autopsy pancreata of T1D patients even beyond the stage of acute infection $[28,30]$. EV can also persist in the intestine [89, 90] and blood cells [91]. These tissues may therefore represent chronic reservoirs from which EV propagates to other organs, such as the pancreas, leading overtime to beta cell autoimmunity. Loss of tolerance of autoreactive $T$ cells against beta cell antigens may also result from deficits in central tolerance secondary to persistent viral infection of thymic cells. CVB4 has been shown to replicate and persist in fetal thymus organ cultures and thymic epithelial cells, thereby impairing $\mathrm{T}$ cell maturation and differentiation [92] and thus decreasing the production of insulin-like growth factor 2 (IGF-2), which might be involved in the establishment of central tolerance toward insulin [93]. 


\section{Conclusions}

In recent years, increasing knowledge has been acquired on how viruses, and especially EVs, can infect beta cells and thus promote insulitis, impair insulin secretion, and trigger beta cell death. However, we still lack mechanistic insight into how a self-limiting acute viral infection, or even a latent virusinduced insulitis, may occasionally evolve into autoimmunity toward beta cells and thus cause T1D. So far, none of the hypotheses accounting for virus-induced beta cell autoimmunity has been supported by stringent evidence in humans, and the involvement of several mechanisms rather than just one is also plausible. Hence, further studies on the potential link between EV infections and T1D are warranted before strategies such as vaccines or antiviral drugs may be pursued as a means to prevent or halt the development of the disease.

Acknowledgments We thank Merja Roivainen for discussion and Ezio Bonifacio and Alberto Pugliese for critical reading of the manuscript. Work in this field in the Solimena lab has been financially supported by EU-FP7 DIAPREPP and the German Center for Diabetes Research (DZD e.V.).

\section{Compliance with Ethics Guidelines}

Conflict of Interest Antje Petzold, Klaus-Peter Knoch, and Michele Solimena declare that they have no conflict of interest.

Human and Animal Rights and Informed Consent This article does not contain any studies with human or animal subjects performed by any of the authors.

Open Access This article is distributed under the terms of the Creative Commons Attribution 4.0 International License (http:// creativecommons.org/licenses/by/4.0/), which permits unrestricted use, distribution, and reproduction in any medium, provided you give appropriate credit to the original author(s) and the source, provide a link to the Creative Commons license, and indicate if changes were made.

\section{References}

Papers of particular interest, published recently, have been highlighted as:

- Of importance

• Of major importance

1. DIAMOND Project Group. Incidence and trends of childhood type 1 diabetes worldwide 1990-1999. Diabet Med. 2006;23: 857-66. doi:10.1111/j.1464-5491.2006.01925.x.

2. Patterson CC, Dahlquist GG, Gyürüs E, et al. Incidence trends for childhood type 1 diabetes in Europe during 1989-2003 and predicted new cases 2005-20: a multicentre prospective registration study. Lancet. 2009;373:2027-33. doi:10.1016/S0140-6736(09)60568-7.

3. Barrett JC, Clayton DG, Concannon P, et al. Genome-wide association study and meta-analysis find that over 40 loci affect risk of type 1 diabetes. Nat Genet. 2009;41:703-7. doi:10.1038/ng.381.
4. Davies JL, Kawaguchi Y, Bennett ST, et al. A genome-wide search for human type 1 diabetes susceptibility genes. Nature. 1994;371:130-6. doi:10.1038/371130a0.

5. Rønningen KS, Keiding N, Green A, et al. Correlations between the incidence of childhood-onset type I diabetes in Europe and HLA genotypes. Diabetologia. 2001;44 Suppl 3:B51-9.

6. Redondo MJ, Yu L, Hawa M, Mackenzie T, et al. Heterogeneity of type I diabetes: analysis of monozygotic twins in Great Britain and the United States. Diabetologia. 2001;44:354-62. doi:10.1007/ s001250051626.

7. Hyttinen V, Kaprio J, Kinnunen L, et al. Genetic liability of type 1 diabetes and the onset age among 22,650 young Finnish twin pairs: a nationwide follow-up study. Diabetes. 2003;52:1052-5.

8. Bodansky HJ, Staines A, Stephenson C, et al. Evidence for an environmental effect in the aetiology of insulin dependent diabetes in a transmigratory population. BMJ. 1992;304:1020-2.

9. Delli AJ, Lindblad B, Carlsson A, et al. Type 1 diabetes patients born to immigrants to Sweden increase their native diabetes risk and differ from Swedish patients in HLA types and islet autoantibodies. Pediatr Diabetes. 2010;11:513-20. doi:10.1111/j.1399-5448.2010.00637.x.

10. Pak CY, Eun HM, McArthur RG, et al. Association of cytomegalovirus infection with autoimmune type 1 diabetes. Lancet. 1988;2:1-4.

11. Chikazawa K, Okusa H, Minakami H, et al. Acute onset of insulindependent diabetes mellitus caused by Epstein-Barr virus infection. Nippon Sanka Fujinka Gakkai Zasshi. 1985;37:453-6.

12. Khakpour M, Nik-Akhtar B. Diabetes mellitus following a mumps epidemic. J Trop Med Hyg. 1975;78:262-3.

13. Helmke K, Otten A, Willems W. Islet cell antibodies in children with mumps infection. Lancet. 1980;2:211-2.

14. Honeyman MC, Coulson BS, Stone NL, et al. Association between rotavirus infection and pancreatic islet autoimmunity in children at risk of developing type 1 diabetes. Diabetes. 2000;49:1319-24.

15. Forrest JM, Menser MA, Burgess JA. High frequency of diabetes mellitus in young adults with congenital rubella. Lancet. 1971;2:332-4.

16. Craighead JE, McLane MF. Diabetes mellitus: induction in mice by encephalomyocarditis virus. Science. 1968;162:913-4.

17. Serreze DV, Ottendorfer EW, Ellis TM, et al. Acceleration of type 1 diabetes by a coxsackievirus infection requires a preexisting critical mass of autoreactive T-cells in pancreatic islets. Diabetes. 2000;49:708-11.

18. Drescher KM, Kono K, Bopegamage S, et al. Coxsackievirus B3 infection and type 1 diabetes development in NOD mice: insulitis determines susceptibility of pancreatic islets to virus infection. Virology. 2004;329:381-94. doi:10.1016/j.virol.2004.06.049.

19. Tracy S, Drescher KM, Chapman NM, et al. Toward testing the hypothesis that group B coxsackieviruses (CVB) trigger insulindependent diabetes: inoculating nonobese diabetic mice with CVB markedly lowers diabetes incidence. J Virol. 2002;76:12097-111.

20. Gamble DR, Kinsley ML, FitzGerald MG, et al. Viral antibodies in diabetes mellitus. Br Med J. 1969;3:627-30.

21. Gamble DR, Taylor KW. Seasonal incidence of diabetes mellitus. Br Med J. 1969;3:631-3.

22. Yoon JW, Austin M, Onodera T, et al. Isolation of a virus from the pancreas of a child with diabetic ketoacidosis. N Engl J Med. 1979;300:1173-9. doi:10.1056/NEJM197905243002102.

23. Banatvala JE, Bryant J, Schernthaner G, et al. Coxsackie B, mumps, rubella, and cytomegalovirus specific IgM responses in patients with juvenile-onset insulin-dependent diabetes mellitus in Britain, Austria, and Australia. Lancet. 1985;1:1409-12.

24. Hyöty H, Hiltunen M, Knip M, et al. A prospective study of the role of coxsackie $\mathrm{B}$ and other enterovirus infections in the pathogenesis of IDDM. Childhood Diabetes in Finland (DiMe) Study Group. Diabetes. 1995;44:652-7.

25. Green J, Casabonne D, Newton R. Coxsackie B virus serology and type 1 diabetes mellitus: a systematic review of published 
case-control studies. Diabet Med. 2004;21:507-14. doi:10.1111/j. 1464-5491.2004.01182.x.

26. Clements GB, Galbraith DN, Taylor KW. Coxsackie B virus infection and onset of childhood diabetes. Lancet. 1995;346:221-3.

27. Andréoletti L, Hober D, Hober-Vandenberghe C, et al. Detection of coxsackie B virus RNA sequences in whole blood samples from adult patients at the onset of type I diabetes mellitus. J Med Virol. 1997;52:121-7.

28. Ylipaasto P, Klingel K, Lindberg AM, et al. Enterovirus infection in human pancreatic islet cells, islet tropism in vivo and receptor involvement in cultured islet beta cells. Diabetologia. 2004;47: 225-39. doi:10.1007/s00125-003-1297-z.

29. Dotta F, Censini S, van Halteren AGS, et al. Coxsackie B4 virus infection of beta cells and natural killer cell insulitis in recent-onset type 1 diabetic patients. Proc Natl Acad Sci U S A. 2007;104: 5115-20. doi:10.1073/pnas.0700442104.

30. Richardson SJ, Willcox A, Bone AJ, et al. The prevalence of enteroviral capsid protein vp1 immunostaining in pancreatic islets in human type 1 diabetes. Diabetologia. 2009;52:1143-51. doi:10. 1007/s00125-009-1276-0.

31. Yeung W-CG, Rawlinson WD, Craig ME. Enterovirus infection and type 1 diabetes mellitus: systematic review and meta-analysis of observational molecular studies. BMJ. 2011;342:d35.

32. Lee H-S, Briese T, Winkler C, et al. Next-generation sequencing for viruses in children with rapid-onset type 1 diabetes. Diabetologia. 2013;56:1705-11. doi:10.1007/s00125-013-2924-y.

33.• Krogvold L, Edwin B, Buanes T, et al. Detection of a low-grade enteroviral infection in the islets of langerhans of living patients newly diagnosed with type 1 diabetes. Diabetes. 2015;64:1682-7. doi:10.2337/db14-1370. This study provides evidence for EVs in pancreatic biopsy tissue at diagnosis of T1D.

34. Imagawa A, Hanafusa $\mathrm{T}$, Makino $\mathrm{H}$, et al. High titres of $\operatorname{Ig} \mathrm{A}$ antibodies to enterovirus in fulminant type-1 diabetes. Diabetologia. 2005;48:290-3. doi:10.1007/s00125-004-1624-Z.

35. Tanaka S, Nishida Y, Aida K, et al. Enterovirus infection, CXC chemokine ligand 10 (CXCL10), and CXCR3 circuit: a mechanism of accelerated beta-cell failure in fulminant type 1 diabetes. Diabetes. 2009;58:2285-91. doi:10.2337/db09-0091.

36.• Laitinen OH, Honkanen H, Pakkanen O, et al. Coxsackievirus B1 is associated with induction of $\beta$-cell autoimmunity that portends type 1 diabetes. Diabetes. 2014;63:446-55. doi:10.2337/db130619. ere CVBs are clustered into risk and protective viruses and immunological cross-protection is proposed.

37. Oikarinen S, Tauriainen S, Hober D, et al. Virus antibody survey in different European populations indicates risk association between coxsackievirus B1 and type 1 diabetes. Diabetes. 2014;63:655-62. doi: $10.2337 / \mathrm{db} 13-0620$. In this study data is presented to support the presumable role of CVB1 as diabetogenic virus.

38. Lin H-C, Wang C-H, Tsai F-J, et al. Enterovirus infection is associated with an increased risk of childhood type 1 diabetes in Taiwan: a nationwide population-based cohort study. Diabetologia. 2015;58:79-86. doi:10.1007/s00125-014-3400-z.

39. Knowles N, Hovi T, Hyypiä T, et al. Picornaviridae. Virus taxonomy: classification and nomenclature of viruses: Ninth Report of the International Committee on Taxonomy of Viruses, San Diego: Elsevier; 2012, p. 855-80.

40. Ehrenfeld E, Domingo E, Roos RP, editors. The Picornaviruses. Washington, D.C.: ASM Press; 2010.

41. Tracy S, Oberste SM, Drescher KM. Group B Coxsackieviruses. Current Topics in Microbiology and Immunology, vol. 323. Berlin Heidelberg: Springer-Verlag; 2008.

42. Frisk G, Diderholm H. Tissue culture of isolated human pancreatic islets infected with different strains of coxsackievirus B4: assessment of virus replication and effects on islet morphology and insulin release. Int J Exp Diabetes Res. 2000;1:165-75.
43. Hodik M, Lukinius A, Korsgren O, et al. Tropism analysis of two Coxsackie B5 strains reveals virus growth in human primary pancreatic islets but not in exocrine cell clusters in vitro. O Virol J. 2013;7:49-56. doi:10.2174/1874357901307010049.

44. Marroqui Esclapez L, Lopes M, Dos Santos RS, et al. Differential cell autonomous responses determine the outcome of coxsackievirus infections in murine pancreatic $\alpha$ and $\beta$ cells. Elife. 2015;4. doi:10.7554/eLife.06990. Here a possible reason for differences between alpha and beta cells in the clearance of viral infections and susceptibility to autoimmunity is provided.

45. Bergelson JM, Cunningham JA, Droguett G, et al. Isolation of a common receptor for Coxsackie B viruses and adenoviruses 2 and 5. Science. 1997;275:1320-3.

46. Shafren DR, Bates RC, Agrez MV, et al. Coxsackieviruses B1, B3, and B5 use decay accelerating factor as a receptor for cell attachment. J Virol. 1995;69:3873-7.

47. Chehadeh W, Kerr-Conte J, Pattou F, et al. Persistent infection of human pancreatic islets by coxsackievirus B is associated with alpha interferon synthesis in beta cells. J Virol. 2000;74:10153-64.

48. Coyne CB, Bergelson JM. Virus-induced Abl and Fyn kinase signals permit coxsackievirus entry through epithelial tight junctions. Cell. 2006;124:119-31. doi:10.1016/j.cell.2005.10.035.

49. Patel KP, Coyne CB, Bergelson JM. Dynamin- and lipid raftdependent entry of decay-accelerating factor (DAF)-binding and non-DAF-binding coxsackieviruses into nonpolarized cells. J Virol. 2009;83:11064-77. doi:10.1128/JVI.01016-09.

50. Lloyd RE. Translational control by viral proteinases. Virus Res. 2006;119:76-88. doi:10.1016/j.virusres.2005.10.016.

51. Hellen CU, Witherell GW, Schmid M, et al. A cytoplasmic 57$\mathrm{kDa}$ protein that is required for translation of picornavirus RNA by internal ribosomal entry is identical to the nuclear pyrimidine tractbinding protein. Proc Natl Acad Sci U S A. 1993;90:7642-6.

52. Lamphear BJ, Yan R, Yang F, et al. Mapping the cleavage site in protein synthesis initiation factor eIF-4 gamma of the $2 \mathrm{~A}$ proteases from human Coxsackievirus and rhinovirus. J Biol Chem. 1993;268:19200-3.

53. Sommergruber $\mathrm{W}$, Ahorn $\mathrm{H}$, Klump $\mathrm{H}$, et al. 2A proteinases of coxsackie- and rhinovirus cleave peptides derived from eIF-4 gamma via a common recognition motif. Virology. 1994;198:741-5.

54. De Breyne S, Bonderoff JM, Chumakov KM, et al. Cleavage of eukaryotic initiation factor eIF5B by enterovirus $3 \mathrm{C}$ proteases. Virology. 2008;378:118-22. doi:10.1016/j.virol.2008.05.019.

55. Joachims M, Van Breugel PC, Lloyd RE. Cleavage of poly(A)binding protein by enterovirus proteases concurrent with inhibition of translation in vitro. J Virol. 1999;73:718-27.

56. Kerekatte V, Keiper BD, Badorff C, et al. Cleavage of Poly(A)binding protein by coxsackievirus $2 \mathrm{~A}$ protease in vitro and in vivo: another mechanism for host protein synthesis shutoff? J Virol. 1999;73:709-17.

57. Modrow S. Viruses with single-stranded, positive-sense RNA genomes. Molecular Virology, Berlin Heidelberg: Springer-Verlag; 2013

58. Xin L, Xiao Z, Ma X, et al. Coxsackievirus B3 induces crosstalk between autophagy and apoptosis to benefit its release after replicating in autophagosomes through a mechanism involving caspase cleavage of autophagy-related proteins. Infect Genet Evol. 2014;26:95-102. doi:10.1016/j.meegid.2014.05.005.

59. Roivainen M, Ylipaasto P, Savolainen C, et al. Functional impairment and killing of human beta cells by enteroviruses: the capacity is shared by a wide range of serotypes, but the extent is a characteristic of individual virus strains. Diabetologia. 2002;45:693702. doi:10.1007/s00125-002-0805-x.

60. Colli ML, Nogueira TC, Allagnat F, et al. Exposure to the viral byproduct dsRNA or Coxsackievirus B5 triggers pancreatic beta cell apoptosis via a Bim/Mcl-1 imbalance. PLoS Pathog. 2011;7: e1002267. doi:10.1371/journal.ppat.1002267. 
61. Richardson SJ, Leete P, Bone AJ, et al. Expression of the enteroviral capsid protein VP1 in the islet cells of patients with type 1 diabetes is associated with induction of protein kinase $\mathrm{R}$ and downregulation of Mcl-1. Diabetologia. 2013;56:185-93. doi:10. 1007/s00125-012-2745-4. This study supports previous data for activation of antiviral response and enhanced apoptosis in infected beta cells.

62. Roivainen M, Rasilainen S, Ylipaasto P, et al. Mechanisms of coxsackievirus-induced damage to human pancreatic beta-cells. J Clin Endocrinol Metab. 2000;85:432-40. doi:10.1210/jcem.85.1. 6306.

63.• Knoch K-P, Nath-Sain S, Petzold A, et al. PTBP1 is required for glucose-stimulated cap-independent translation of insulin granule proteins and Coxsackieviruses in beta cells. Mol Metab. 2014;3: 518-30. doi:10.1016/j.molmet.2014.05.002. Here evidence for cap-independent PTBP1-mediated translation of SG proteins and CVB RNA is presented. Hence, translation of SG protein is not inhibit upon CVB infection and therefore is not the cause for reduced SG stores and insulin secretion.

64.• Ylipaasto P, Smura T, Gopalacharyulu P, et al. Enterovirusinduced gene expression profile is critical for human pancreatic islet destruction. Diabetologia. 2012;55:3273-83. doi:10.1007/ s00125-012-2713-z. In this study virus strain-specific changes in gene expression of infected beta cells are addressed for proinflammatory response and necrosis.

65. Ylipaasto P, Kutlu B, Rasilainen S, et al. Global profiling of coxsackievirus- and cytokine-induced gene expression in human pancreatic islets. Diabetologia. 2005;48:1510-22. doi:10.1007/ s00125-005-1839-7.

66. Skog O, Korsgren O, Frisk G. Modulation of innate immunity in human pancreatic islets infected with enterovirus in vitro. J Med Virol. 2011;83:658-64. doi:10.1002/jmv.21924.

67. Olsson A, Johansson U, Korsgren $\mathrm{O}$, et al. Inflammatory gene expression in Coxsackievirus B-4-infected human islets of Langerhans. Biochem Biophys Res Commun. 2005;330:571-6. doi:10.1016/j.bbrc.2005.03.016.

68. Schulte BM, Lanke KHW, Piganelli JD, et al. Cytokine and chemokine production by human pancreatic islets upon enterovirus infection. Diabetes. 2012;61:2030-6. doi:10.2337/db11-1547.

69. Foulis AK, Farquharson MA, Meager A. Immunoreactive alphainterferon in insulin-secreting beta cells in type 1 diabetes mellitus. Lancet. 1987;2:1423-7.

70. Coppieters KT, Dotta F, Amirian N, et al. Demonstration of isletautoreactive CD8 T cells in insulitic lesions from recent onset and long-term type 1 diabetes patients. J Exp Med. 2012;209:51-60. doi:10.1084/jem.20111187.

71. Rasilainen S, Ylipaasto P, Roivainen M, et al. Mechanisms of coxsackievirus B5 mediated beta-cell death depend on the multiplicity of infection. J Med Virol. 2004;72:586-96. doi:10.1002/ jmv.20043.

72. Willcox A, Richardson SJ, Bone AJ, et al. Immunohistochemical analysis of the relationship between islet cell proliferation and the production of the enteroviral capsid protein, VP1, in the islets of patients with recent-onset type 1 diabetes. Diabetologia. 2011;54: 2417-20. doi:10.1007/s00125-011-2192-7.

73. Yap IS, Giddings G, Pocock E, et al. Lack of islet neogenesis plays a key role in beta-cell depletion in mice infected with a diabetogenic variant of coxsackievirus B4. J Gen Virol. 2003;84:305168.

74. Gallagher GR, Brehm MA, Finberg RW, et al. Viral infection of engrafted human islets leads to diabetes. Diabetes. 2015;64:1358 69. doi: $10.2337 / \mathrm{db} 14-1020$.

75. Craig ME, Nair S, Stein H, et al. Viruses and type 1 diabetes: a new look at an old story. Pediatr Diabetes. 2013;14:149-58. doi: 10.1111/pedi.12033.
76. Seewaldt S, Thomas HE, Ejrnaes M, et al. Virus-induced autoimmune diabetes: most beta-cells die through inflammatory cytokines and not perforin from autoreactive (anti-viral) cytotoxic Tlymphocytes. Diabetes. 2000;49:1801-9.

77. Stassi G, De Maria R, Trucco G, et al. Nitric oxide primes pancreatic beta cells for Fas-mediated destruction in insulindependent diabetes mellitus. J Exp Med. 1997;186:1193-200.

78. Horwitz MS, Bradley LM, Harbertson J, et al. Diabetes induced by Coxsackie virus: initiation by bystander damage and not molecular mimicry. Nat Med. 1998;4:781-5.

79. Von Herrath MG, Allison J, Miller JF, et al. Focal expression of interleukin-2 does not break unresponsiveness to "self" (viral) antigen expressed in beta cells but enhances development of autoimmune disease (diabetes) after initiation of an anti-self immune response. J Clin Invest. 1995;95:477-85. doi:10.1172/JCI117688.

80. Holz A, Brett K, Oldstone MB. Constitutive beta cell expression of IL-12 does not perturb self-tolerance but intensifies established autoimmune diabetes. J Clin Invest. 2001;108:1749-58. doi:10. 1172/JCI13915.

81. Atkinson MA, Bowman MA, Campbell L, et al. Cellular immunity to a determinant common to glutamate decarboxylase and coxsackie virus in insulin-dependent diabetes. J Clin Invest. 1994;94:2125-9. doi:10.1172/JCI117567.

82. Richter W, Mertens T, Schoel B, et al. Sequence homology of the diabetes-associated autoantigen glutamate decarboxylase with coxsackie B4-2C protein and heat shock protein 60 mediates no molecular mimicry of autoantibodies. J Exp Med. 1994;180:7216.

83. Schloot NC, Willemen SJ, Duinkerken G, et al. Molecular mimicry in type 1 diabetes mellitus revisited: T-cell clones to GAD65 peptides with sequence homology to Coxsackie or proinsulin peptides do not crossreact with homologous counterpart. Hum Immunol. 2001;62:299-309.

84. Honeyman MC, Stone NL, Harrison LC. T-cell epitopes in type 1 diabetes autoantigen tyrosine phosphatase IA-2: potential for mimicry with rotavirus and other environmental agents. Mol Med. 1998;4:231-9.

85. Honeyman MC, Stone NL, Falk BA, et al. Evidence for molecular mimicry between human $\mathrm{T}$ cell epitopes in rotavirus and pancreatic islet autoantigens. J Immunol. 2010;184:2204-10. doi:10. 4049/jimmunol.0900709.

86. Härkönen T, Lankinen H, Davydova B, et al. Enterovirus infection can induce immune responses that cross-react with beta-cell autoantigen tyrosine phosphatase IA-2/IAR. J Med Virol. 2002;66:340-50

87. Yin H, Berg A-K, Westman J, et al. Complete nucleotide sequence of a Coxsackievirus B-4 strain capable of establishing persistent infection in human pancreatic islet cells: effects on insulin release, proinsulin synthesis, and cell morphology. J Med Virol. 2002;68: 544-57. doi:10.1002/jmv.10236.

88. Tracy S, Smithee S, Alhazmi A, et al. Coxsackievirus can persist in murine pancreas by deletion of 5' terminal genomic sequences. J Med Virol. 2015;87:240-7. doi:10.1002/jmv.24039.

89. Oikarinen M, Tauriainen S, Honkanen T, et al. Detection of enteroviruses in the intestine of type 1 diabetic patients. Clin Exp Immunol. 2008;151:71-5. doi:10.1111/j.1365-2249.2007.03529.x.

90. Oikarinen M, Tauriainen S, Oikarinen S, et al. Type 1 diabetes is associated with enterovirus infection in gut mucosa. Diabetes. 2012;61:687-91. doi:10.2337/db11-1157.

91. Schulte BM, Bakkers J, Lanke KHW, et al. Detection of enterovirus RNA in peripheral blood mononuclear cells of type 1 diabetic patients beyond the stage of acute infection. Viral Immunol. 2010;23:99-104. doi:10.1089/vim.2009.0072.

92. Brilot F, Jaïdane H, Geenen V, et al. Coxsackievirus B4 infection of murine foetal thymus organ cultures. J Med Virol. 2008;80: 659-66. doi:10.1002/jmv.21016. 
93. Jaïdane H, Caloone D, Lobert P-E, et al. Persistent infection of thymic epithelial cells with coxsackievirus B4 results in decreased expression of type 2 insulin-like growth factor. J Virol. 2012;86: 11151-62. doi:10.1128/JVI.00726-12.

94. Henke A, Launhardt H, Klement K, et al. Apoptosis in coxsackievirus B3-caused diseases: interaction between the capsid protein VP2 and the proapoptotic protein siva. J Virol. 2000;74:4284-90.

95. Gradi A, Svitkin YV, Imataka H, et al. Proteolysis of human eukaryotic translation initiation factor eIF4GII, but not eIF4GI, coincides with the shutoff of host protein synthesis after poliovirus infection. Proc Natl Acad Sci U S A. 1998;95:11089-94.

96. Seipelt J, Liebig HD, Sommergruber W, et al. 2A proteinase of human rhinovirus cleaves cytokeratin 8 in infected HeLa cells. J Biol Chem. 2000;275:20084-9.

97. Wang B, Xi X, Lei X, et al. Enterovirus 71 protease 2Apro targets MAVS to inhibit anti-viral type I interferon responses. PLoS Pathog. 2013;9:e1003231. doi:10.1371/journal.ppat.1003231.

98. Feng Q, Langereis MA, Lork M, et al. Enterovirus 2Apro targets MDA5 and MAVS in infected cells. J Virol. 2014;88:3369-78. doi:10.1128/JVI.02712-13.

99. Gustin KE, Sarnow P. Effects of poliovirus infection on nucleocytoplasmic trafficking and nuclear pore complex composition. EMBO J. 2001;20:240-9. doi:10.1093/emboj/20.1.240.

100. Park N, Katikaneni P, Skern T, et al. Differential targeting of nuclear pore complex proteins in poliovirus-infected cells. J Virol. 2008;82:1647-55. doi:10.1128/JVI.01670-07.

101. Calandria C, Irurzun A, Barco A, et al. Individual expression of poliovirus 2Apro and 3Cpro induces activation of caspase-3 and PARP cleavage in HeLa cells. Virus Res. 2004;104:39-49. doi:10. 1016/j.virusres.2004.02.042.

102. Shi J, Wong J, Piesik P, et al. Cleavage of sequestosome $1 / \mathrm{p} 62$ by an enteroviral protease results in disrupted selective autophagy and impaired NFKB signaling. Autophagy. 2013;9:1591-603. doi:10.4161/auto.26059.

103. Rust RC, Landmann L, Gosert R, et al. Cellular COPII proteins are involved in production of the vesicles that form the poliovirus replication complex. J Virol. 2001;75:9808-18. doi:10.1128/JVI. 75.20.9808-9818.2001.

104. Wang J, Wu Z, Jin Q. COPI is required for enterovirus 71 replication. PLoS ONE. 2012;7:e38035. doi:10.1371/journal.pone. 0038035.

105. De Jong AS, Wessels E, Dijkman HBPM, et al. Determinants for membrane association and permeabilization of the coxsackievirus $2 \mathrm{~B}$ protein and the identification of the Golgi complex as the target organelle. J Biol Chem. 2003;278:1012-21. doi:10.1074/jbc. M207745200.

106. Van Kuppeveld FJ, Hoenderop JG, Smeets RL, et al. Coxsackievirus protein $2 \mathrm{~B}$ modifies endoplasmic reticulum membrane and plasma membrane permeability and facilitates virus release. EMBO J. 1997;16:3519-32. doi:10.1093/emboj/16. 12.3519 .

107. De Jong AS, Visch H-J, de Mattia F, et al. The coxsackievirus 2B protein increases efflux of ions from the endoplasmic reticulum and Golgi, thereby inhibiting protein trafficking through the Golgi. J Biol Chem. 2006;281:14144-50. doi:10.1074/jbc.M511766200.

108. Belov GA, Fogg MH, Ehrenfeld E. Poliovirus proteins induce membrane association of GTPase ADP-ribosylation factor. J Virol. 2005;79:7207-16. doi:10.1128/JVI.79.11.7207-7216.2005.

109. Wessels E, Duijsings D, Niu T-K, et al. A viral protein that blocks Arf1-mediated COP-I assembly by inhibiting the guanine nucleotide exchange factor GBF1. Dev Cell. 2006;11:191-201. doi:10. 1016/j.devcel.2006.06.005.
110. Belov GA, Altan-Bonnet N, Kovtunovych G, et al. Hijacking components of the cellular secretory pathway for replication of poliovirus RNA. J Virol. 2007;81:558-67. doi:10.1128/JVI. 01820-06.

111. Deitz SB, Dodd DA, Cooper S, et al. MHC I-dependent antigen presentation is inhibited by poliovirus protein 3A. Proc Natl Acad Sci U S A. 2000;97:13790-5. doi:10.1073/pnas.250483097.

112. Li W, Ross-Smith N, Proud CG, et al. Cleavage of translation initiation factor 4AI (eIF4AI) but not eIF4AII by foot-and-mouth disease virus $3 \mathrm{C}$ protease: identification of the eIF4AI cleavage site. FEBS Lett. 2001;507:1-5.

113. Kuyumcu-Martinez NM, Joachims M, Lloyd RE. Efficient cleavage of ribosome-associated poly(A)-binding protein by enterovirus 3C protease. J Virol. 2002;76:2062-74.

114. Joachims M, Harris KS, Etchison D. Poliovirus protease $3 \mathrm{C}$ mediates cleavage of microtubule-associated protein 4. Virology. 1995;211:451-61. doi:10.1006/viro.1995.1427.

115. Lei X, Han N, Xiao X, et al. Enterovirus $713 \mathrm{C}$ inhibits cytokine expression through cleavage of the TAK1/TAB1/TAB2/TAB3 complex. J Virol. 2014;88:9830-41. doi:10.1128/JVI.01425-14.

116. Xiang Z, Li L, Lei X, et al. Enterovirus 68 3C protease cleaves TRIF to attenuate antiviral responses mediated by Toll-like receptor 3. J Virol. 2014;88:6650-9. doi:10.1128/JVI.03138-13.

117. Mukherjee A, Morosky SA, Delorme-Axford E, et al. The coxsackievirus B 3C protease cleaves MAVS and TRIF to attenuate host type I interferon and apoptotic signaling. PLoS Pathog. 2011;7:e1001311. doi:10.1371/journal.ppat.1001311.

118. Back SH, Kim YK, Kim WJ, et al. Translation of polioviral mRNA is inhibited by cleavage of polypyrimidine tract-binding proteins executed by polioviral 3C(pro). J Virol. 2002;76:252942.

119. Perera R, Daijogo S, Walter BL, et al. Cellular protein modification by poliovirus: the two faces of poly $(\mathrm{rC})$-binding protein. $\mathrm{J}$ Virol. 2007;81:8919-32. doi:10.1128/JVI.01013-07.

120. Clark ME, Hämmerle T, Wimmer E, et al. Poliovirus proteinase $3 \mathrm{C}$ converts an active form of transcription factor IIIC to an inactive form: a mechanism for inhibition of host cell polymerase III transcription by poliovirus. EMBO J. 1991;10:2941-7.

121. Clark ME, Lieberman PM, Berk AJ, et al. Direct cleavage of human TATA-binding protein by poliovirus protease $3 \mathrm{C}$ in vivo and in vitro. Mol Cell Biol. 1993;13:1232-7.

122. Weidman MK, Sharma R, Raychaudhuri S, et al. The interaction of cytoplasmic RNA viruses with the nucleus. Virus Res. 2003;95: 75-85.

123. Barco A, Feduchi E, Carrasco L. Poliovirus protease $3 \mathrm{C}($ pro) kills cells by apoptosis. Virology. 2000;266:352-60. doi:10.1006/viro. 1999.0043.

124. Zhang H, Cong H, Song L, et al. The nuclear protein Sam68 is redistributed to the cytoplasm and is involved in PI3K/Akt activation during EV71 infection. Virus Res. 2014;180:1-11. doi:10. 1016/j.virusres.2013.11.020.

125. Rozovics JM, Chase AJ, Cathcart AL, et al. Picornavirus modification of a host mRNA decay protein. MBio. 2012;3:e0043100412. doi:10.1128/mBio.00431-12.

126. Chase AJ, Daijogo S, Semler BL. Inhibition of poliovirus-induced cleavage of cellular protein PCBP2 reduces the levels of viral RNA replication. J Virol. 2014;88:3192-201. doi:10.1128/JVI. 02503-13.

127. Belov GA, Habbersett C, Franco D, et al. Activation of cellular Arf GTPases by poliovirus protein 3CD correlates with virus replication. J Virol. 2007;81:9259-67. doi:10.1128/JVI.00840-07. 